\title{
Investigating The Mediating Role Of Service Innovation In Firm Performance: An Empirical Research
}

\author{
Arif Mohammad Arshad, Xi' an Jiaotong University, China \\ Jie Wang, Xi' an Jiaotong University, China \\ Qin Su, Xi'an Jiaotong University, China
}

\begin{abstract}
The aim of this paper is to investigate the relationship between total quality management (TQM), service innovation and firm performance in the Pakistan's service industry. An empirical survey was performed and there were 190 participants from financial service firms in Pakistan. Regression analysis was employed in this study to investigate the tri-dimensional relationship between TQM, service innovation and firm performance. In the context of financial firms, this research examines how TQM practices adopted and managed to boost service innovation and whether and how TQM practices is going to influence the firm performance through the mediating role of service innovation. A research framework and the related hypotheses are suggested. Direct and indirect impact of each construct of TQM practices on organizational performance was determined. Data analysis discloses that, extent of TQM implementation has a positive and significant influence on service innovation as well as on organizational performance. Furthermore, a positive but a weak relationship was observed between service innovation and organizational performance. The direct relationship between TQM and organizational performance outperforms the indirect relationship of service innovation and organizational performance. It has contributed in the sense that past researchers have not considered the tri-dimensional relationship between TQM, service innovation and firm performance.
\end{abstract}

Keywords: TQM; Service Innovation; Firm Performance; Process Innovation; Product Innovation

\section{INTRODUCTION}

Q ervice sector is a labour-intensive sector. It is essential that a top quality relationship between workforce and customers are retained. In general, in a modern day market, the service industry is of greatest value regarding its involvement in developing the worldwide market (Lam et al., 2012; Samat et al., 2006). Modern day service industry is required to deliver outstanding services in an attempt to succeed in extremely sophisticated competitive local and international industries (Sultan and Simpson, 2000). The importance of the service industry is growing in regional and global economies. There has been a huge rise in the service industry contribution to the GNP from the developed countries in the last two decades. Business activities have gone through the largest levels of development and growth due to inclusion of innovation in service industry. A significant area of the overseas investments is being added in the service industry in Pakistan because of its lucrative marketplace, safe future and huge potential of expansion and advancement. Because of this, exactly why the service industry of Pakistan is developing with high speed when assessed with the other countries of the region. The financial experts are operating to redirect the foundation of economic system from agricultural to commercial and service driven to become at par with the developed countries (Qureshi et al., 2008).

TQM is amongst the most globally acknowledged top-quality solution to accomplish higher quality services and products (Waldman, 1994), and leading to superior firm performance (Cook, 2002). The employment of TQM practices in the key service industries turned out to be more appealing, because TQM practices assist firms to provide top quality services and accomplish greater customer satisfaction (Lam et al., 2012). TQM is a holistic management philosophy seeking persistent enhancement in all capacities of firm to create and offer products or 
services consistent with customers' wants or needs through superior, low cost, quicker, reliable, effortless refinement than rivals through the involvement of all workforce under the direction of top management. The functions of TQM are widely known as providing essential determining factor in the accomplishment and existence of both service and manufacturing firms in present competitive conditions. TQM is also described as an approach to obtain change and creation of new business culture (Irani et al., 2004), innovation (Singh and Smith, 2004), competitive benefit (Douglas and Judge, 2001). Any decline in customer satisfaction as a result of substandard service quality could result in severe problems that may lead to firm failure. Buyers are getting increasingly conscious of growing specifications in product/service quality, motivated by competitive movements, which have created increased expectations (Demirbag et al., 2006).

In an extremely limited time, globalisation has evolved the entire world economic order, offering with it fresh challenges and new business prospects. Innovation worth a particular consideration these days because of its significance for businesses to be able to conform to the international market standards in terms of delivering customized remedies for customers. Customers are evolving into more advanced, segmented and challenging, and demand more regarding customization, innovation, price and quality (Simon et al., 2012; Stark, 2011). Services are $75 \%$ of the USA GDP and expanding. Manufacturing companies desire service innovations for customer retention and advancement. Services companies desire new service innovations for customer satisfaction, growth and productivity. Services are actually crucial for businesses in all industries and of all sizes. To compete in the market, continual innovation in services is essential. Due to the fact many services can be easily copied once out there in the marketplace, continuous innovation will distinguish the industry leaders from the remaining group. Due to this reason services require co-creation of value and rely on co-ordination of processes in and out of the firm, much is still undiscovered about service innovation. Service innovation is paramount to survival over these rapid evolving times. Customer desires are swiftly evolving, and service is the distinction between bankrupt and competitive companies. Companies must compel themselves to determine one's destiny. Innovation is the major protection to commoditization. Services imply survival. Needs change with time. The ones that populate those needs will be required to transform as well (Pal \& Zimmerie, 2005). Innovation comprises a process of taking advantage of fresh ideas effectively to be able to boost competitive position in the market (Danjum \& Rasli, 2012).

According to innovation perspective, the assessment of the influence of TQM on innovation performance is essential, leading to the introduction of managerial routines that may be employed as an effective tool for figuring out innovation performance (Prajogo \& Sohal, 2006). These days innovation has been acknowledged as more useful than in the past. In an effort to accomplish good performance, firms should embrace both innovation and quality. The connection between TQM and innovation has produced substantial curiosity about the role of management practices in service firms (Feng et al., 2006). In the present literature, there is no sort of outcome suggested particular TQM practices that results in attaining both service innovation and financial and non-financial firm performance in service firms. Most of the past research works only studied the influence of TQM dimensions on innovation (Abrunhosa \& Moura E Sá, 2008; Thai Hoang et al., 2009; Prajogo, \& Sohal, 2003). The key goal of this research is to figure out the outcome of implementation of TQM practices together with service innovation on financial and non-financial firm performance of service firms in Pakistan. Past studies have not considered the tridimensional connection between TQM, service innovation and firm performance of service firms and therefore studies are being essential in this field. This study looks into the essential competencies of three constructs, namely TQM, service innovation and firm performance of service firms, and investigates the tri-dimensional relationship between these three constructs, in an effort to accomplish higher financial and non-financial firm performance and the accomplishment of a greater service innovation. This research investigates the direct and indirect influence of each construct on financial and non-financial firm performance. Furthermore, research investigates the effectiveness of relationship between TQM, service innovation and firm performance along with the relationship between service innovation and firm performance. The aim of the research is also to evaluate the direct and indirect effect of TQM practices and service innovation on firm performance and to investigate the mediating role of service innovation in order to improve the business performance of the firm. 


\section{LITERATURE REVIW AND RESEARCH FRAMEWORK}

\subsection{TQM}

Total quality management (TQM) are the quality-driven practices that numerous firms recommend. TQM has magnetized scholars due to the expanding diffusion and approval in the industrial world (Rahman, 2005; Zehir et al., 2012). The triumph associated with TQM will lead to enhanced staff engagement, better communication, higher output, better quality and fewer changes, lowered costs of bad quality, greater competitive benefit and superior customer satisfaction (Antony et al., 2002). TQM is an organization culture dedicated to satisfaction of customers by means of continuous growth. This culture differs from country to country amongst various industries; however, has a particular necessary standard, which can be implemented to acquire higher share of the market, elevated earnings, and lowered expenses (Kanji and Wallace, 2000). The effective execution of TQM assists firms in improving techniques and services that can't be copied with ease by the rivals (Dale, 2003). TQM focus on growth and development of procedures and approaches which are economical that emphasis on the tasks being completed from the beginning with least waste of resources from business operations (Lam, 2012). The essential purpose of TQM is to become more competitive, sales growth, creativity and enhancing organization business performance. After extensive reviews of past literature review, the researchers have chosen the following list of seven key practices of TQM setup related to our study. All practices are determined because of their effectiveness and importance towards the service organization. Continuous improvement and Customer focus and are some of the key dimensions of quality which has been nearly included in all past research endeavour (Samat et al., 2006). These dimensions include: Top management support, Customer focus, ICT usage, Continuous improvement, service culture, Knowledge sharing and Information system quality.

\subsection{Relationship Between TQM and Service Innovation}

Service innovation is a crucial aspect of firm's ability to set apart itself from its rivals and increase the firm's sales. Innovations can boost service differentiation; hence it is important for managers to put into action these innovations which are wanted by the people to yield earnings for the organization. According to recent literature, there is positive and significant relationship between innovation and firms' performance in different service sectors (Lin, 2011). Firms that distinctly outline their innovation procedures for services are tend to be more fast and profitable in creating new services. The growth and development of new services results in greater sales growth along with surge in the proportion of their overall income. Today's business environment is extremely demanding and thus merely delivering quality services isn't sufficient, firms ought to search for new innovative service choices which are invaluable for customers (Bettencourt et al., 2013). Hence firms need to give extra focus to their innovation strategy, procedures and particularly their services to ensure more systematic innovation process (Schulteß et al., 2010). Profitable innovation practices tend to be more beneficial during the economic downturn when there's reduction in business activities because of lower investments. Service innovation is a huge resource for competitive edge for all those firms that take advantage of information obtained via consumers, rivals and enjoy the capability to build more significant and distinctive services.

Due to presence of variety of TQM practices, the relationship between TQM and innovation is of compound nature (Bon \& Mustafa, 2012 in press). The research carried out by McAdam et al (1998) in Ireland discovered that firms need to enhance their continuous improvement strategies since they offer basis for developing an innovation firm. An additional perspective is that innovative firms operate in more organized style owing to number of factors. First, they know the customer's wants and secondly they're faster than their rivals in creating innovative products or services. Lastly, they abide by the ISO 90001 quality standards (Mielgo et al, 2009). However, Leavengood and Anderson (2011) discovered that quality driven organizations aren't innovative since they over concentrate on the customer wants and therefore are assertive in the direction of customer wants. Based on the research of Singh \& Smith(2004) there isn't any obvious empirical proof of positive and critical influence of TQM on innovation, although (Prajogo and Sohal, 2003) suggested that TQM practices might have negative impact on innovation owing to numerous practices. Furthermore, the majority of the research had been completed in developed countries. There's insufficient study regarding the mediating role of service innovation practices between TQM and firms financial and non-financial business performance in developing nations. 


\subsection{Relationship Between TQM and Firm Financial Performance}

Initial facts appear to suggest that TQM-adopting organizations acquire a competitive edge over companies that don't embrace TQM (Powell, 1995; Brah et al., 2002). Companies that give attention to continuous improvement, including encourage employees to accomplish high quality results and concentrate on pleasing customers are more inclined to perform better than companies that don't have this aim (Joiner, 2007). Continuous improvement on the job processes was rated the key activity for boosting the short-term profitability, whereas enhancing customer focus was graded the most crucial activity for strengthening long-term well-being of the company (Soderquist et al., 1997).

The fundamental theoretical platform for the relationship between the successful setup of TQM approaches and financial performance is founded on two predicted connections. First, TQM targets the firms' endeavours to build and keep customers, those results in improved earnings through attaining a market gain, and diminished costs by means of product design proficiency. Second, TQM concentrates on the organization's work to boost the processes that develop their products and services, which results in higher income via product stability, and diminished expenses via process performance efficiency (George and Weimerskirch, 1998; York \& Miree, 2004). In an investigation of 20 research studies of the effect of TQM performed by a number of business associations, consulting firms and membership organizations including the American Society for Quality Control and Conference Board. It was found that TQM can enhance company performance, share of the market, process costs and return on investments (York \& Miree, 2004). Reed et al. (1996) claim that the content of TQM may be identified depending on the two business orientations: customer orientation and process orientation. Customer orientated firms concentrate on attaining market advantages where they are able to perform better than their competitors regarding gaining more customers with outstanding products and ask for a premium price. According to past studies TQM approach that targets improving customer's degrees of fulfilment can have a vital influence on firm's performance (Terzioski and Samson, 2000). Ittner and Larcker(1996), for instance, proposed that achieving customer satisfaction is believed to boost the earnings of the firm by reducing costs by means of less returns and enhancing profits via customer loyalty. In the course of the production process, the customer could ask for having access to the quality information utilized in statistical process control, to determine the standard of the products. Quality is, indeed, mainly a customer belief depending on how nicely the product or service satisfies the customers' expectations and standards (Waldman and Gopalakrishnan, 1996). There's substantial historical proof on the level in which TQM improves the prospect of firms to boost organizational performance (Gharakhani et al., 2013).

Despite the fact that TQM has its foundations in manufacturing associated firms, it is commonly regarded as its concepts are significantly associated to service firms because both utilize resources as information to meet customers' wants (Brah et al., 2000). Well-known management strategies of service organizations with effective quality programs comprise of incorporation of TQM with performance assessment tools, coaching managers to resolve problems, continuous transmission of quality message, customer involvement and quality process structure (Warihay, 1993). According to survey of the advertising market of Singapore to recognize the vital success components appropriate for TQM, suggest TQM as a good approach to enhance earnings, organizational efficiency, customer satisfaction and competitiveness (Brah et al., 2000). Using all prior into account, it's hypothesized that: H1. TQM can positively influence a firm's financial performance.

\subsection{Relationship Between TQM and Firm Non-Financial Performance}

Usually, financial indicators such as growth rate, earnings, market share and inter alia profit are used to measure the organizational performance. According to Kaplan and Norton (1996) the financial indicators only describe the past performance of the firm. Therefore, they added non-financial indicators in an effort to get over potential flaws of conventional organizational performance systems. The key goal of any business firm is to achieve the financial performance. The indicators such as market share, innovation performance (Llorens et al., 2003), and other nonfinancial performance clues may be crucial in making use of TQM principles (Demirbag et al., 2006). Further, rendering of TQM dimensions can also have indirect influence on financial performance (Kaynak, 2003). Malik et al. (2010) investigated the effect of total quality management programs on non-financial performance in SMEs. Malik et al. (2010) found positive connection between TQM principles and non-financial performance. Furthermore, Malik et al. (2010) determined that benchmarking and supplier relationships are the most important principles for 
non-financial performance. Samson and Terziovski (1999) discovered the positive connection between implementation of TQM practices and some non-financial measures such as innovation growth, cost of quality, export growth, market share growth, etc. Lee (2004) found that positive relationship between TQM practices and non-financial performance measures such as sales improvement, cost improvement and production performance. Chong and Rundus (2004) investigated the influence of TQM and market competition on organizational performance by researching the manufacturing firms. Results indicated that there's a positive relationship between market competition and TQM practices of product design, customer focus and organizational performance. There are few studies that describe the relationship between TQM practices and non-financial performance in service firms in the past literature. Using the previous arguments, we analyse the following hypothesis.

H2: TQM can positively influence a firm's non-financial performance.

Figure 1. Proposed Research Model Service Innovation Practices

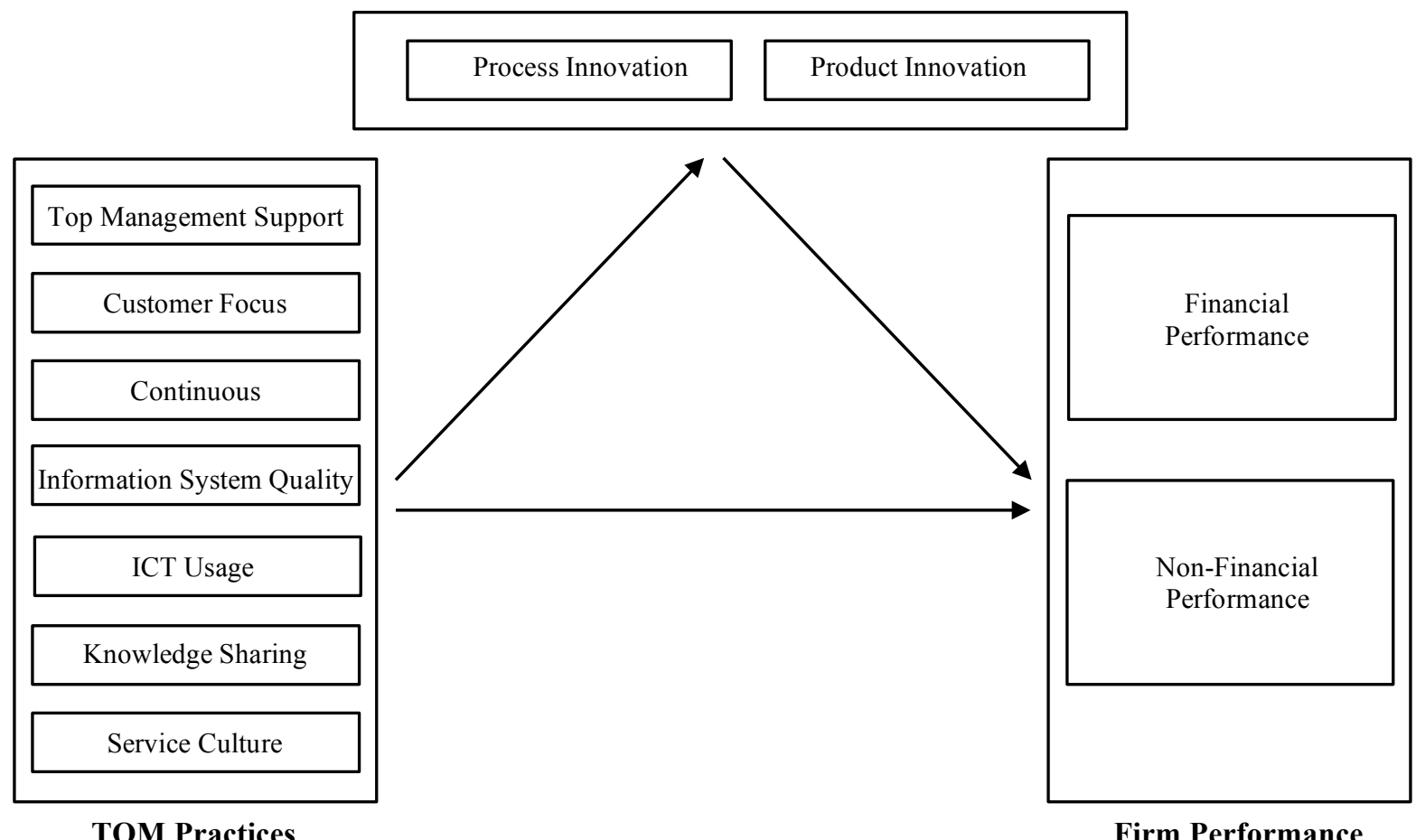

\subsection{Relationship Between TQM and Product Innovation}

The aim of product innovation is to fulfil the needs and demands of the customers or seize foreign markets. Service product innovations are the unveiling of new items in the heart of existing services is the virtually basic type of innovation that may bring about new business rewards. The objective of service innovation is to improve the existing services and make them more appealing to customers with the addition of new tastes in the heart of already present services (Khazanchi et al., 2007). The TQM principles of customer focus encourage organizations to discover new customer desires and consequently lead firms to be innovative regarding discovering new products on regular basis in an effort to satisfy market's evolving demands (Juran, 1988). Firms who embrace TQM as an organization strategy tend to be more innovative firms (Baldwin and Johnson, 1996). The service firms that carry out TQM principles will be more effective in differentiating their products and services. The TQM principle leadership urges employees to deliver new suggestions for fixing problems for creating new products or services. There is significant relationship between TQM principles and product innovation (Prajogo and Hong, 2008). However, product innovation could be a base for competitive advantage but only for a short time, because rivals often copy the new and productive product innovations (Zhang et al., 2000; Simon et al., 2012). According to the research conducted by Prajogo \& Sohal(2004) on manufacturing and non-manufacturing firms there is positive and significant link between product and process innovation and TQM principles. Hoang et al (2006) studied the 
influence of TQM practices on innovation in Vietnam. They included both manufacturing and services firms in their research study. Their results revealed that TQM has a positive effect on innovation regarding the number of new products or service offered or created and also on level of the newness. According to previous arguments, we can assume that:

H3: There is positive relationship between TQM implementation and product innovation

\subsection{Relationship Between TQM and Process Innovation}

The purpose of Process innovation is to enhancing the effectiveness of the firm by developing or enhancing production techniques or services along with the advancements in the expansion of processes, systems and reengineering pursuits to enable new products or services (Khazanchi et al., 2007; Garcia and Calantone , 2002). Most of managers give more importance on process innovation as compared to product innovation, since the most of past literature is in favour of opinion that some process innovations can entirely transform the way a product is developed and in fact it is a kind of innovation that considerably decreases costs (Dess et al., 2006). From an innovation perspective, TQM principles suits the class of value-leader that puts significant emphasis on process innovation and less focus on product innovation (Gobeli and Brown ,1994). According to Oke (2007) processes upgrades are crucial for the achievement of product/service innovation. The products and services improvements are key sign of firm's profitability and market share. Therefore, organizations should continuously enhance their products and services (Deming, 1986). According to research conducted by Prajogo \& Sohal (2004) on manufacturing and non-manufacturing firms, satisfied customers boost firm's earnings by repeat purchase of products or services. They also found that TQM principles are positively correlated with product and process innovations. The continuous improvements lead to innovations in the firm and bring about improvements in the firms. The innovative marketing that targets expanding product usage has a positive impact on organization sales. According to previous arguments, we can assume that:

H4: There is positive relationship between TQM implementation and process innovation.

\subsection{Relationship Between Service Innovation and Firm Performance}

Innovation has been a major element in sustaining global competition. It empowers firm expansion, leads to long term achievements, and it's the vehicle that enables businesses to preserve their stability in worldwide economy (Gaynor, 2002). For businesses seeking brilliance in this age of restructuring, cutting down costs and high competition, improving product or service quality aren't enough. Therefore, businesses must be capable of generate and commercialize a supply of new products and procedures that expand the technology frontier, simultaneously holding a stride or two ahead of their competitors (Porter and Stern, 2001; Yeh-Yun Lin \& Yi-Ching Chen, 2007). The business expansion of an organization goes downhill rather very fast as soon as it's begins giving up the idea of newness and innovation (Metcalfe, 1998). The innovation in any organization is very important if it wants to expand, maintain, and become competitive (McAdam \& Keogh, 2004). The research conducted by Yeh-Yun Lin and YiChing Chen (2007) found that product and process innovation has positive and significant influence on firm performance. Geroski et al. (1993), while studying the manufacturing firms in UK, discovered that the quantity of innovations has positive and significant influence on their operating profit margin. Roberts (1999) performed longitudinal study in the U.S. pharmaceutical sector in order to test the impact of product innovativeness on the sustainable profitability of firms. He found significant relationship between sustained superior profitability and high product innovation propensity. Artz et al. (2010), in their longitudinal study in various sectors of the U.S. and Canada, they analysed the effects of patents obtained and product innovations on firm performance. They discovered significant influence of product innovation on firm performance. Therrien et al. (2011) explored whether innovation has an influence over firm performance in chosen service sectors. The final results revealed that in an effort to gain additional profits from innovations, firms should join the market earlier or to bring in new products with significant degrees of uniqueness. Cainelli et al. (2006) investigated the relationship between innovation and performance in depth, and figured out that there's a two-way relationship: innovative firms perform better than non-innovators, but superior performing firms are also going to innovate, and commit an increased amount of their resources to innovation. In reality, an increasing number of researchers indicate that service innovations facilitate firms to achieve competitive advantage (Kaplan, 2000). According to (Soderquist, 1996) in order to improve the short-term 
profitability of the firm, the continuous work process innovations are viewed as the most vital activity. There's a connection between innovation and sales turnover growth in SME (Oke, 2007). Process innovation can also increase the performance of operations (e.g., Tushman \& Nadler 1986). It makes sense that firms that continuously innovate service processes would master at applying new marketing strategies and improving customer satisfaction to satisfy the constantly evolving wants of their customers. Moreover, introducing new products and strengthening present products assist firms grow their sales and turn out to be market leaders (e.g., Iansiti 1995). Delivering new service products to suit customer needs would facilitate firms to have pace with the changing needs of customers and assist in improving brand image. Furthermore, caring for customer wants contributes to sustainable achievement in business operations (Chen \& Tsou, 2007; Henard \& Szymanski 2001). Based on above arguments we can assume that:

H5a: Process innovation can positively influence a firm financial performance.

H5b: Process innovation can positively influence a firm non-financial performance.

H6a: Product innovation can positively influence a firm financial performance.

H6b: Product innovation can positively influence a firm non-financial performance.

\section{RESEARCH METHODOLOGY}

The unit of study is financial sector in Pakistan. In this research, survey questionnaire was used to analyse the interactions amongst TQM practices, Service innovation, and financial and non-financial firm's performance in the financial sector. We received details about TQM practices, service innovation and firm's performance from various financial firms in Pakistan. The information extracted from survey questionnaire were utilised to study the effect of TQM practices on service innovation and firm's performance. We choose financial service firms to conduct these studies. The selection of financial market is due to the fact it's very competitive, technology driven and dynamic industry. As a result of swift improvement in the business conditions of financial services industry, there's fast rise in the usage of innovation-related pursuits within the financial services industry (Chen et al., 2007).

The five-point Likert scale was implemented from past researches for computing our constructs. The survey questionnaire comprised of four-page self-administered questionnaire earlier employed in comparison of quality management practices in various studies. The participants of the survey were most experienced people concerning researching challenges of this research. Total of 300 questionnaires were circulated. 190 questionnaires with thorough feedback were received that indicate an overall response rate of $63 \%$. The data is accumulated from ISO certified firms from financial services industry of Pakistan. The statistical tool such as regression analysis was put into practice to interpret the data. We used SPSS 20 to interpret our data.

\subsection{Measures}

This research includes seven TQM dimensions that are top management support, customer focus, continuous improvement, quality information system, ICT usage, service culture and knowledge sharing. The questions relevant to TQM dimensions chosen in this research are derived from past researches of Brah et al. (2002), Sureshchandar et al. (2002) and Prajogo and Sohal (2006). The scale of process innovation was adopted from Chen et al. (2007) and Davenport and Short (1990). The questions regarding product innovation were adopted and modified from the research work of Chen et al. (2007) and Avlonitis et al. (2001). Organizational performance was determined by elements produced from past research works of (Rao, 2006; Hoang et al., 2006). The organizational performance consists of financial and non-financial indicators.

\subsection{Verification of Scales}

The construct validity was examined by applying exploratory factor analysis (EFA). The function of using EFA is to separate the dimensions of each and every construct. The factors were eliminated through the use of principal component analysis separately on firm's performance, TQM and Service innovation criteria with varimax rotation. 
The factor loading of at least 0.30 is regarded as adequate variable (Nunnally, 1967). To guarantee quality of extracted elements, a factor loading of at least 0.50 was regarded appropriate. Through the entire validation process items with factor loading under 0.5 were eventually removed (Sit et al., 2009; Hoang et al., 2006). The outcomes of EFA are described in Table $1 \&$ Table 2 . The entire reliability values are over 0.5 that demonstrates all the measures in this research are correct and reliable. The internal consistency analysis was performed to examine the reliability of survey data. The Cronbach's alpha is the standard way of measuring the reliability showing relative reliability of each factor being a scale. The adequate significant value of Cronbach's alpha is 0.6(Nunnally, 1967). To be able to enhance the reliability, elements with values under 0.6 were removed (Shams-ur Rahman, 2001). The entire reliability coefficient values in this research are over 0.7 that reveal that each and every factor is satisfactorily reliable measure. The appropriateness of the sample was analysed through the use of KMO measure. The KMO values revealed under in table $1 \&$ Table 2 are likely to be tolerable (Shams-ur Rahman, 2001; Kim and Mueller, 1978).

Table 1. Factor analysis of TQM practices

\begin{tabular}{|c|c|c|c|c|}
\hline Variable & Loadings & KMO & Variance $(\%)$ & Cronbach's alpha \\
\hline Top management support & & 0.763 & 56.632 & 0.731 \\
\hline TM1 & 0.689 & & & \\
\hline TM2 & 0.685 & & & \\
\hline TM3 & 0.743 & & & \\
\hline TM4 & 0.943 & & & \\
\hline TM5 & 0.834 & & & \\
\hline Customer Focus & & 0.815 & 71.194 & 0.865 \\
\hline CF1 & 0.764 & & & \\
\hline CF2 & 0.754 & & & \\
\hline CF3 & 0.737 & & & \\
\hline CF4 & 0.593 & & & \\
\hline Continuous improvement & & 0.796 & 66.435 & 0.826 \\
\hline CI1 & 0.693 & & & \\
\hline $\mathrm{CI} 2$ & 0.667 & & & \\
\hline $\mathrm{CI} 3$ & 0.609 & & & \\
\hline CI4 & 0.689 & & & \\
\hline Information system quality & & 0.690 & 60.958 & 0.801 \\
\hline IS1 & 0.685 & & & \\
\hline IS2 & 0.574 & & & \\
\hline IS3 & 0.565 & & & \\
\hline IS4 & 0.615 & & & \\
\hline Service Culture & & 0.800 & 73.281 & 0.869 \\
\hline SC1 & 0.760 & & & \\
\hline $\mathrm{SC} 2$ & 0.756 & & & \\
\hline $\mathrm{SC} 3$ & 0.713 & & & \\
\hline SC4 & 0.702 & & & \\
\hline ICT usage & & 0.771 & 69.361 & 0.851 \\
\hline IU1 & 0.848 & & & \\
\hline IU2 & 0.885 & & & \\
\hline IU3 & 0.817 & & & \\
\hline IU4 & 0.778 & & & \\
\hline Knowledge sharing & & 0.808 & 69.448 & 0.850 \\
\hline KS1 & 0.868 & & & \\
\hline KS2 & 0.836 & & & \\
\hline KS3 & 0.846 & & & \\
\hline KS4 & 0.781 & & & \\
\hline
\end{tabular}


Table 2. Factor analysis of firm performance and service innovation practices

\begin{tabular}{c|c|c|c|c}
\hline Variable & Loadings & KMO & Variance (\%) & Cronbach's alpha \\
\hline Financial Performance & & 0.779 & 72.121 & 0.853 \\
\hline FP1 & 0.555 & & & \\
\hline FP2 & 0.737 & & & \\
\hline FP3 & 0.822 & & & \\
\hline FP4 & 0.771 & & & \\
\hline Non-Financial Performance & & & & \\
\hline NFP1 & 0.667 & & & \\
\hline NFP2 & 0.833 & & & \\
\hline NFP3 & 0.665 & & & \\
\hline NFP4 & 0.824 & & & \\
\hline NFP5 & 0.794 & & & \\
\hline SI1 & 0.710 & & & \\
\hline SI2 & 0.628 & & & \\
\hline SI3 & 0.727 & & & \\
\hline SI5 & 0.787 & & & \\
\hline SI6 & 0.680 & & & \\
\hline SI7 & 0.696 & & & \\
\hline
\end{tabular}

\section{DATA ANALYSIS}

\section{Test of Hypothesis H1}

In this hypothesis firm financial performance stands for dependent variable and the seven TQM principles represent independent variables. The outcomes in the table 3 , the value of $\mathrm{R}^{2}=0.725$, which implies 72.5 per cent of variance in firm performance are likely to be explained by the seven TQM dimensions. As reported in the Table 3, Top management support, customer focus, continuous improvement, service culture, ICT usage and knowledge sharing have significant influence on the financial performance. On examining the value of Beta, it could be observed that Continuous Improvement has most crucial influence on financial performance there after Top Management support and knowledge sharing; supporting H1 that the amount of TQM used had a positive and direct influence on firm performance, as shown in Table 3. This result also validates the studies of past studies of Brah et al (2000), Easton and Jarrell (1998), Joiner (2007) and Liu (2007)

Table 3. Regression results between TQM practices and firm financial performance

\begin{tabular}{l|c}
\hline \multicolumn{1}{c}{ Independent Variables } & Standardized Beta \\
\hline Top Management support & $0.274^{* *}$ \\
\hline Customer Focus & $0.133^{* *}$ \\
\hline Continuous Improvement & $0.295^{* *}$ \\
\hline Information System Quality & 0.030 \\
\hline Service Culture & $0.107^{*}$ \\
\hline ICT usage & $0.138^{* *}$ \\
\hline Knowledge Sharing & $0.163^{* *}$ \\
\hline $\mathrm{R}^{2}$ & 0.725 \\
\hline Adjusted $\mathrm{R}^{2}$ & 0.714 \\
\hline F-value & 63.534 \\
\hline
\end{tabular}

Note: ${ }^{*} \mathrm{p}<0.05 ; * \mathrm{p}<0.01$

\section{Test of Hypothesis $\mathbf{H} 2$}

In the hypothesis H2, non-financial performance is dependent variable and the TQM practices used as independent variable. The table 4 demonstrates Customer Focus has most significant impact on the non-financial performance pursued by Continuous Improvement. The value of $\mathrm{R}^{2}$ suggests that 71.7 per cent of the variation in non-financial performance may be described by TQM dimensions. Our results reveal that there is direct link between TQM 
implementation and non-financial performance which is supported according to the findings of Samson and Terziovski (1999), Lee (2004), Chong and Rundus (2004), Brah et al. (2000) and Demirbag et al. (2006)

Table 4. Regression results between TQM practices and firm non-financial performance

\begin{tabular}{l|c}
\hline \multicolumn{1}{c|}{ Independent Variables } & Standardized Beta \\
\hline Top Management support & $0.176^{* *}$ \\
\hline Customer Focus & $0.280^{* *}$ \\
\hline Continuous Improvement & $0.268^{* *}$ \\
\hline Information System Quality & 0.050 \\
\hline Service Culture & 0.080 \\
\hline ICT usage & $0.117^{*}$ \\
\hline Knowledge Sharing & $0.167^{* *}$ \\
\hline $\mathrm{R}^{2}$ & 0.717 \\
\hline Adjusted $\mathrm{R}^{2}$ & 0.706 \\
\hline F-value & 65.992 \\
\hline
\end{tabular}

Note: $* \mathrm{p}<0.05 ; * * \mathrm{p}<0.01$

\section{Test of Hypothesis H3}

In the hypothesis H3, product innovation is dependent variable and the TQM practices taken as independent variable. The table 5 signifies that continuous improvement has most significant effect on the service product innovation and then ICT usage. The value of $\mathrm{R}^{2}$ shows that 39.3 per cent of the variance in product innovation could be explained by TQM dimensions. This finding confirms the results of (Prajogo, \& Sohal, 2003) \& (Arshad \& Su, 2015).

Table 5. Regression results between TQM practices and product innovation

\begin{tabular}{l|c}
\hline \multicolumn{1}{c|}{ Independent Variables } & Standardized Beta \\
\hline Top Management support & 0.137 \\
\hline Customer Focus & -0.139 \\
\hline Continuous Improvement & $0.338^{* *}$ \\
\hline Information System Quality & 0.108 \\
\hline Service Culture & 0.028 \\
\hline ICT usage & $0.151^{*}$ \\
\hline Knowledge Sharing & 0.135 \\
\hline $\mathrm{R}^{2}$ & 0.393 \\
\hline Adjusted $\mathrm{R}^{2}$ & 0.370 \\
\hline F-value & $16.845^{* *}$ \\
\hline Note: ${ }^{*}<0.05 ; * * p<0.01$ &
\end{tabular}

\section{Test of Hypothesis H4}

In the hypothesis H4, process innovation is a dependent variable and the TQM practices are independent variables. Depending on the value of Beta, it's obvious from the table 6 that top management support is most impacted variable pursued by knowledge sharing and continuous improvement. The value of $\mathrm{R}^{2}$ suggests that 68.3 per cent of the variance in process innovation could be explained by TQM dimensions. This finding also confirms the results of (Prajogo, \& Sohal, 2003) and (Arshad \& Su, 2015). 
Table 6. Regression results between TQM practices and process innovation

\begin{tabular}{l|c}
\hline \multicolumn{1}{c|}{ Independent Variables } & Standardized Beta \\
\hline Top Management support & $0.271^{* *}$ \\
\hline Customer Focus & 0.038 \\
\hline Continuous Improvement & $0.220^{* *}$ \\
\hline Information System Quality & $0.150^{*}$ \\
\hline Service Culture & 0.068 \\
\hline ICT usage & $0.127^{*}$ \\
\hline Knowledge Sharing & $0.241^{* *}$ \\
\hline $\mathrm{R}^{2}$ & 0.683 \\
\hline Adjusted $\mathrm{R}^{2}$ & 0.671 \\
\hline F-value & $56.032^{* *}$
\end{tabular}

Note: $* \mathrm{p}<0.05 ; * * \mathrm{p}<0.01$

\section{Test of Hypothesis H5a}

In the hypothesis H5a, financial performance is a dependent variable and the process innovation is an independent variable. The table 7 shows that process innovation is positively linked to financial performance. The value of $\mathrm{R}^{2}$ suggests that 49.4 per cent of the variation in financial performance may be explained by process innovation. This finding also confirms the outcomes of (Soderquist, 1996), (Varis \& Littunen, 2010) and (Atalay et al., 2013).

Table 7. Regression results between financial performance and process innovation

\begin{tabular}{l|c}
\hline \multicolumn{1}{c}{ Independent Variables } & Standardized Beta \\
\hline Process Innovation & $0.703^{* *}$ \\
\hline $\mathrm{R}^{2}$ & 0.494 \\
\hline Adjusted $\mathrm{R}^{2}$ & 0.491 \\
\hline F-value & 183.448 \\
\hline Note $* \mathrm{p}<0.05 * * * \mathrm{p}<0.01$ &
\end{tabular}

Note: ${ }^{*} \mathrm{p}<0.05 ; * * \mathrm{p}<0.01$

\section{Test of Hypothesis H5b}

In the hypothesis $\mathrm{H} 5 \mathrm{~b}$, non- financial performance is a dependent variable and the process innovation is an independent variable. The table 8 signifies that process innovation is positively related to non-financial performance. The value of $\mathrm{R}^{2}$ shows that 50.1 per cent of the variation in non-financial performance could be explained by process innovation. This finding also confirms the outcomes of (Varis \& Littunen, 2010) and (Morone and Testa, 2008) and (Chen \& Tsou, 2007).

Table 8. Regression results between non-financial performance and process innovation

\begin{tabular}{l|c}
\hline \multicolumn{1}{c|}{ Independent Variables } & Standardized Beta \\
\hline Process Innovation & $0.708^{* *}$ \\
\hline $\mathrm{R}^{2}$ & 0.501 \\
\hline Adjusted $\mathrm{R}^{2}$ & 0.499 \\
\hline F-value & $\mathbf{1 8 8 . 8 8 1}$ \\
\hline Note: ${ }^{*} \mathrm{p}<0.05 ; * * \mathrm{p}<0.01$ &
\end{tabular}

\section{Test of Hypothesis H6a}

In the hypothesis H6a, financial performance is a dependent variable and the product innovation is an independent variable. The table 9 suggests that product innovation is positively linked to financial performance. The value of $\mathrm{R}^{2}$ signifies that 29.8 per cent of the variation in financial performance could be explained by product innovation. This finding also confirms the outcomes of Roberts (1999), Cooper and Kleinschmidt (1986), Therrien et al. (2011), Gunday et al. (2011) and Atalay et al. (2013). 
Table 9. Regression results between financial performance and product innovation

\begin{tabular}{l|c}
\hline \multicolumn{1}{c|}{ Independent Variables } & Standardized Beta \\
\hline Product Innovation & 0.545 \\
\hline $\mathrm{R}^{2}$ & 0.298 \\
\hline Adjusted $\mathrm{R}^{2}$ & 0.294 \\
\hline F-value & 79.619 \\
\hline Note: $* \mathrm{p}<0.05 * * * \mathrm{p}<0.01$ &
\end{tabular}

Note: ${ }^{*} \mathrm{p}<0.05 ; * \mathrm{*}<0.01$

\section{Test of Hypothesis H6b}

In the hypothesis $\mathrm{H} 6 \mathrm{~b}$ non-financial performance is a dependent variable and the product innovation is an independent variable. The table 8 shows that product innovation is positively linked to non-financial performance. The value of $\mathrm{R}^{2}$ shows that 26.7 per cent of the variance in non-financial performance can be explained by product innovation. This finding also confirms the outcomes of (Varis \& Littunen, 2010), (Cre 'pon et al., 1998), (Morone, and Testa, 2008), (Wolff and Pett, 2006) and (Chen \& Tsou,2007).

Table 10. Regression results between non-financial performance and product innovation

\begin{tabular}{l|c}
\hline \multicolumn{1}{c|}{ Independent Variables } & Standardized Beta \\
\hline Product Innovation & 0.516 \\
\hline $\mathrm{R}^{2}$ & 0.267 \\
\hline Adjusted $\mathrm{R}^{2}$ & 0.263 \\
\hline F-value & 68.315 \\
\hline
\end{tabular}

Note: ${ }^{*} \mathrm{p}<0.05 ; * \mathrm{p}<0.01$

\section{DISCUSSIONS}

Making use of TQM principles to facilitate firm performance has turned into a key strategy in many firms. Earlier studies have recommended that TQM principles perform significant part in a firm's capability to improve firm performance by means of innovations in products and services. This research designed a research framework and empirically explored the outcomes of TQM adoption on firm performance through mediating role of service innovation. This research investigated the TQM-performance relationship and secondly, the mediated role of service innovation between TQM practices and firm performance. This research researches the connections between TQM, service innovations and firm performance for the service firms. This study provides empirical verification contributing to the features of TQM that may be observed on service innovations, and subsequently on firm performance. The results of this research demonstrate that direct impact of the important elements of TQM on firm performance has more influence than in-direct effect mediated by service innovation on financial performance. We can say that from this relationship that implementation of TQM is far more focused in the direction of firm performance than service innovation. This shows that TQM is more related to firm performance than service innovation. Additionally, TQM practices convey a greater justification on financial performance than on nonfinancial performance. We also endeavour to construct a connection between the two areas of this study by examining the gap in the level of associations between TQM and organizational performance together with the mediating role of service innovation between TQM practices and firm performance. As recognized by the outcomes, TQM has a strongest connection with financial performance followed by non-financial performance and finally process innovation. These results reveal that firm financial and non-financial performance measures are explained by the execution of TQM practices.

All these results of significant causal relationships among the three performance factors support the theoretical proposition recommending a positive relationship between service innovation and firm performance. There exists little empirical research that looks at a triangulation of TQM, service innovation and organizational performance within the perspective of service firms, with past studies nonetheless mainly analysing all these hypotheses either discretely or in a two-way relationship. The uniqueness of this study is based on the introduction of service innovation practices whilst inspecting the connection between TQM practices and organizational performance in service firms. During this research, regression analysis was applied to generate empirically tested and confirmed fundamental measurements of TQM, service innovation and organizational performance respectively. 


\section{MANAGERIAL IMPLICATIONS}

The successful implementation of TQM practices leads to improvement in service innovation. The successful implementation of TQM practices develops and foster a corporate culture that embraces change and new ways of carrying out work that produces value for customers and stockholders, bring out greater yields, higher quality, and a competitive edge for the firm. It results in more innovation and enables the implementation of new ideas that brings out higher innovation success and leads to process and product innovation.

Outcomes of this research revealed that Continuous Improvement and Top Management support was positively associated with financial performance and had the strong influence on financial performance as opposed to other practices. Also, Continuous Improvement and Customer Focus had strong influence on non-financial performance. Service organizations therefore look forward to discover remedies on how to enhance these practices to improve firm performance. Service managers should bring continuous improvements through small changes instead of radical changes, look for new approaches, make use of knowledge gained from the past experiences, ideas from experiences workers, and explore new methods in order to bring improvements in current processes. Service managers can enhance firm performance through customer focus. The customer focus brings about greater customer satisfaction. Superior customer satisfaction may have an immediate and positive influence on financial performance mainly because they have witnessed an improved service than before and superior to that offered by alternative or similar suppliers. They're quite likely going to turn out to be repeat buyers and become more loyal. Organisations are usually in a position to draw in new customers due to outstanding or superior service delivery through innovation, superior utilization of services for customers and efficient utilisation of IT and their expertise to promote these developments. Appealing to new customers may imply greater income as well as an improved market share, and, providing the services offered are lucrative, this can bring about improved revenue (Johnston and Clark, 2001).

Through the viewpoint of practice, showing that diverse TQM practices influence firm performance as compared to service innovation has numerous benefits for managing service firms. It is essential to understand which unique TQM practices promote the service innovation and firm performance in service firms. Managers should focus on modifying the TQM practices that encourages the service innovation and firm performance in their particular organizations. This research has contributed to the current literature by means of an improved knowledge on the suggested structural associations between TQM, service innovation and firm performance where the structural link between constructs can be established using regression analysis. As long as the suggested structural model is concerned, this research presents some proof for a positive impact of TQM practices on service innovation, as well as on firm performance.

Similarly, process innovation and product innovation practices also boost firm performance. The process innovation plays bigger role towards firm performance. The service innovations improve productivity through greater customer satisfaction and increased customer loyalty which often raise competitive advantage. Service managers should take advantage of new and promising business development technologies and solutions to deliver new products and services to market quicker than their competitors and that can lead to significant profits.

\section{CONCLUSION \& RESEARCH IMPLICATIONS}

The results offer empirical proof that TQM significantly and positively enhances service innovation, in relation to both product and process innovation. Its involvement to service innovation, nevertheless, appears to be lesser to that of firm performance. In line with theoretical concerns, a model was suggested connecting the two constructs of TQM and service innovation to the firm performance. Regression analysis was then employed to analyse the model in financial services industry.

From the theoretic viewpoint, this research exhibited the significance of TQM practices in the service industry. Additionally, it provides contribution to the literature with regards to the influence of TQM practices on firm performance and service innovation. There is a lack of empirical research which examines a triangulation of TQM, service innovation and firm performance regarding service firms, with prior research nevertheless mainly analysing these paradigms either in a two-way relationship or discretely. The uniqueness of this study is due to the mediating role of service innovation while examining the connection between TQM and organizational performance in service 
firms. The outcomes revealed that TQM had a positive direct influence on service innovation; likewise, a positive and strong relationship was observed regarding the degree of TQM execution and organizational performance. Lastly, it was discovered that mediating role of service innovation, the TQM practices also had a positive and significant influence on organizational performance. This result could not verify the opinion that a triangulation of TQM, service innovation and firm performance is better than two-way relationship between TQM implementation and firm performance. The results suggest a positive and significant relationship between service innovation and firm performance, especially process innovation.

\section{AUTHOR INFORMATION}

Arif Mohammad Arshad is a doctorate student at Xi'an Jiaotong University in China.

E-mail: marshadarif@yahoo.com

Jie Wang is s female doctorate student at Xi 'an Jiaotong University School of Management, Ph.D. Major research topics include quality management.

E-mail:19881206wj@163.com

Dr. Qin Su is a professor, doctoral supervisor, at Xi 'an Jiaotong University, Vice President of the College of Management. Major research areas including quality management and supply chain management.

E-mail: qinsu@mail.xjtu.edu.cn

\section{ACKNOWLEDGEMENT}

I gratefully acknowledge the support and generosity of The Humanities and Social Sciences of Ministry of Education Planning Fund (13YJA630078), China, without which the present study could not have been completed.

\section{REFERENCES}

Antony, J., Leung, K., Knowles, G. and Gosh, S. (2002). Critical success factors of TQM implementation in Hong Kong industries. International Journal of Quality and Reliability Management, 19(5), 551-66.

Arshad, A.M., \& Su, Q., (2015). Role Of Total Quality Management In Service Innovations: An Empirical Study Of Pakistan's Financial Services Firms. The Journal of Applied Business Research, 31(3), 891-910.

Artz, K.W., Norman, P.M., Hatfield, D.E. and Cardinal, L.B. (2010). A longitudinal study of the impact of r\&d, patents, and product innovation on firm performance. Journal of Product Innovation Management, 27(5), pp.725-740.

Atalay, M., Anafarta, N., \& Sarvan, F. (2013). The relationship between innovation and firm performance: empirical evidence from Turkish automotive supplier industry. Procedia-Social and Behavioral Sciences, 75, 226-235.

Atalay, M., Anafarta, N., \& Sarvan, F. (2013). The relationship between innovation and firm performance: empirical evidence from Turkish automotive supplier industry. Procedia-Social and Behavioral Sciences, 75, 226-235.

Avlonitis, G.J., Papastathopoulou, P. G. \& Gounaris, S.P. (2001). An empirically-based typology of product innovativeness for new financial services: success and failure scenarios. Journal of Product Innovation Management, 18(5), 324-342.

Baldwin, J. R., \& Johnson, J. (1996). Business strategies in more-and less-innovative firms in Canada. Research policy, 25(5), 785-804.

Bettencourt, L. A., Brown, S. W., \& Sirianni, N. J. (2013). The secret to true service innovation. Business Horizons, 56(1), 13-22.

Bon, A. T. and Mustafa, E. M. A. (2013). Impact of Total Quality Management on Innovation in Service Organizations: Literature Review and New Conceptual Framework. Procedia Engineering, 53,516-529.

Brah, S. A., Li Wong, J., \& Madhu Rao, B. (2000). TQM and business performance in the service sector: a Singapore study. International Journal of Operations \& Production Management, 20(11), 1293-1312.

Brah, S. A., Li Wong, J., \& Madhu Rao, B. (2000). TQM and business performance in the service sector: a Singapore study. International Journal of Operations \& Production Management, 20(11), 1293-1312.

Brah, S.A., Serene T.S.L. and Rao, B.M. (2002). Relationship between TQM and performance of Singapore companies. International Journal of Quality and Reliability Management, 19(4), 356-79.

Brah, S.A., Serene T.S.L. and Rao, B.M. (2002). Relationship between TQM and performance of Singapore companies. International Journal of Quality and Reliability Management, 19(4), 356-79.

Cainelli, G., Evangelista, R., Savona, M. (2006). Innovation and economic performance in services: a firm-level analysis. Cambridge Journal of Economics, 30, 435-458.

Chen, J.S. \& Tsou, H.T. (2007). Information technology adoption for service innovation practices and competitive advantage: the case of financial firms. Information Research, 12(3). 
Chong, V. K., \& Rundus, M. J. (2004). Total quality management, market competition and organizational performance. The British Accounting Review, 36(2), 155-172.

Chong, V.K. and Rundus, M.J. (2004). Total quality management, market competition and organizational performance. British Accounting Review, 36, 155-72.

Chong, V.K. and Rundus, M.J. (2004). Total quality management, market competition and organizational performance. British Accounting Review, 36, 155-72.

Cook, L. S. (2002). Exploring the linkages between quality system, service quality, and performance excellence: service providers' perspectives. Quality Management Journal, 9(2), 44-56.

Cooper, R.G. and Kleinschmidt, E. (1986). An investigation into the new product process: deficiencies and impact", Journal of Product Innovation Management, 3(2), 71-85.

Cre 'pon, B., Duguet, E. and Mairesse, J. (1998). Research, innovation and productivity:an econometric analysis at the firm level. Economics of Innovation and New Technology, 7(2), 115-58.

Dale, B.G. (2003). TQM: an overview, in Dale, B.G. (Ed.), Managing Quality (4th ed.). Oxford: Blackwell Publishing.

Danjum, I., \& Rasli, A. (2012). Imperatives of service innovation and service quality for customer satisfaction: Perspective on higher education. Procedia-Social and Behavioral Sciences, 40, 347-352.

Davenport, T. H. \& Short, J. E. (1990). The new industrial engineering: information technology and business process redesign. Sloan Management Review, 31(4), 11-27.

Deming, W.E., (1986). Out of the Crisis. Cambridge, MA: MIT Press.

Demirbag, M., Lenny Koh, S. C., Tatoglu, E., \& Zaim, S. (2006). TQM and market orientation's impact on SMEs' performance. Industrial Management \& Data Systems, 106(8), 1206-1228.

Demirbag, M., Tatoglu, E., Tekinkus, M., \& Zaim, S. (2006). An analysis of the relationship between TQM implementation and organizational performance: Evidence from Turkish SMEs. Journal of manufacturing technology management, 17(6), 829-847.

Demirbag, M., Tatoglu, E., Tekinkus, M., \& Zaim, S. (2006). An analysis of the relationship between TQM implementation and organizational performance: Evidence from Turkish SMEs. Journal of manufacturing technology management, 17(6), $829-847$.

Dess, G., Lumpkin, G.T. and Eisner, A.B. (2006). Strategic Management: Text and Cases. McGraw-Hill, Boston, MA.

Douglas, T.J. and Judge, W.Q. Jr (2001). Total quality management implementation and competitive advantage: the role of structural control and exploration. Academy of Management Journal, 44(1), 158-69.

Easton, G. S., \& Jarrell, S. L. (1998). The Effects of Total Quality Management on Corporate Performance: An Empirical Investigation*. The Journal of Business, 71(2), 253-307.

Feng, J., Prajogo, D. I., Chuan Tan, K., \& Sohal, A. S. (2006). The impact of TQM practices on performance: A comparative study between Australian and Singaporean organizations. European Journal of Innovation Management, 9(3), 269-278.

Abrunhosa, A., \& Moura E Sá, P. (2008). Are TQM principles supporting innovation in the Portuguese Footwear industry? Technovation, 28(4), 208-221.

Garcia, R., and Calantone, R. (2002). A critical look at technological innovation typology and innovativeness terminology: A Literature review. The Journal of Product Innovation Management, 19(2), 110-132.

Gaynor, G.H. (2002). Innovation by Design: What it Takes to Keep Your Company on the cutting edge. AMACOM American management association, New York, NY.

George, S., Weimerskirch, A.,(1998). Total Quality Management:

Strategies and Techniques Proven at Today's Most Successful Companies. Wiley, New York, NY.

Geroski, P., Machin, S. and Van Reenen, J. (1993). The profitability of innovating firms. Rand Journal of Economics, 24(2), 198211.

Gharakhani, D., Rahmati, H., Farrokhi, M. R., \& Farahmandian, A. (2013). Total quality management and organizational performance. American Journal of Industrial Engineering, 1(3), 46-50.

Gobeli, D.H. and Brown, W.B. (1994). Technological innovation strategies. Engineering Management Journal. 6 (1), $17-24$.

Gunday, G., Ulusoy, G., Kilic, K., \& Alpkan, L. (2011). Effects of innovation types on firm performance. International Journal of Production Economics, 133(2), 662-676.

Henard, D. H. \& Szymanski, D. M. (2001). Why some new products are more successful than others. Journal of Marketing Research, 38(3), 362-375.

Hoang, D. T., Igel, B., \& Laosirihongthong, T. (2006). The impact of total quality management on innovation: Findings from a developing country. International Journal of Quality and Reliability Management, 23(9), 1092 - 1117.

Hoang, D. T., Igel, B., \& Laosirihongthong, T. (2006). The impact of total quality management on innovation: Findings from a developing country. International Journal of Quality and Reliability Management, 23(9), 1092 - 1117.

Iansiti, M. (1995). Shooting the rapids: managing product development in turbulent environments. California Management Review, 38(1), 37-58.

Irani, Z., Beskese, A. and Love, P.E.D. (2004). Total quality management and corporate culture: constructs of organizational excellence. Technovation, 24, 643-50.

Ittner, C. D., \& Larcker, D. F. (1996). Measuring the impact of quality initiatives on firm financial performance. Advances in the 
management of organizational quality, 1(1), 1-37.

Johnston, R. and Clark, G. (2001). Service Operations Management. Pearson Education Ltd, Essex.

Joiner, T. A. (2007). Total quality management and performance: The role of organization support and co-worker support. International Journal of Quality \& Reliability Management, 24(6), 617-627.

Joiner, T. A. (2007). Total quality management and performance: The role of organization support and co-worker support. International Journal of Quality \& Reliability Management, 24(6), 617-627.

Kanji, G.K. and Wallace, W. (2000). Business excellence through customer satisfaction. Total Quality Management, 11(7), 97998.

Kaplan, R.S. and Norton, D.P. (1996), The Balanced Scorecard: Translating Strategy into Action. Harvard Business School Press, Boston, MA.

Kaplan, S.M., (2000). Innovating Professional Services, Consulting to Management, 11 (1), 30-34.

Kaynak, H. (2003). The relationship between total quality management practices and their effects on firm performance. Journal of Operations Management, 21, 405-35.

Khazanchi, S., Lewis, M.W. and Boyer, K. (2007). Innovation-supportive culture: the impact of organizational values on process innovation. Journal of Operations Management, 25(4), 871-84.

Khazanchi, S., Lewis, M.W. and Boyer, K. (2007). Innovation-supportive culture: the impact of organizational values on process innovation. Journal of Operations Management, 25(4), 871-84.

Juran, J.M., (1988). Juran on Planning for Quality. New York,NY: The Free Press.

Kim,J. \& Mueller,C.(1978). Introduction to Factor Analysis. Beverly Hills, CA: Sage Publications.

Lam, S.-Y., V.-H. Lee, et al. (2012). A structural equation model of TQM, market orientation and service quality: Evidence from a developing nation. Managing Service Quality, 22(3), 281-309.

Lam, S.-Y., V.-H. Lee, et al. (2012). A structural equation model of TQM, market orientation and service quality: Evidence from a developing nation. Managing Service Quality, 22(3), 281-309

Leavengood, S., \& Anderson, T. R. (2011). Best practices in quality management for innovation performance. Technology Management in the Energy Smart World (PICMET). 2011 Proceedings of PICMET '11, 1-9.

Lee, C.Y. (2004). Perception and development of total quality management in small manufacturers: an exploratory study in China. Journal of Small Business Management, 42(1), 102-15.

Lee, C.Y. (2004). Perception and development of total quality management in small manufacturers: an exploratory study in China. Journal of Small Business Management,42(1),102-15

Liu, F. C. (2007). The effects of total quality management on business performance: Evidence from Taiwan information-related industries.

Llorens, F.J., Ruiz, A. and Molina, L.M. (2003). An analysis of the relationship between quality and perceived innovation: the case of financial firms. Industrial Management \& Data Systems, 103, 579-90.

Malik, S. A., Iqbal, M. Z., Shaukat, R., \& Yong, J. (2010). TQM practices \& organizational performance: evidence from Pakistani SMEs. International Journal of Engineering \& Technology, 10(4), 26-31.

McAdam, R., \& Keogh, W. (2004). Transitioning towards creativity and innovation measurement in SMEs. Creativity and Innovation Management, 13(2), 126-139.

McAdam, R., Armstrong, G. \& Kelly, B. (1998). Investigation of the relationship between total quality and innovation: a research study involving small organizations. European Journal of Innovation Management, 1(3), 139-147.

Metcalfe, J. S. (Ed.). (1998). Evolutionary economics and creative destruction (Vol. 1). Psychology Press

Mielgo N. P., Poen-Monters J. M, Ordas-Vazquez C. J. (2009). Are quality and innovation management conflicting activities? Technovation, 29(8), 537-545.

Morone, P. and Testa, G. (2008). Firms growth, size and innovation: an investigation into the Italian manufacturing sector. Economics of Innovation and New Technology, 17(4), 311-29.

Morone, P. and Testa, G. (2008). Firms' growth, size and innovation: an investigation into Italian manufacturing sector. Economics of Innovation and New Technology, 17(4), 311-29.

Nunnally, J. (1967). Psychometric Theory. New York, NY: McGraw-Hill.

Oke, A. (2007). Innovation types and innovation management practices in service companies. International Journal of Operations \& Production Management, 27(6), 564 - 587.

Pal, N., \& Zimmerie, R. (2005). Service innovation: a framework for success. White Paper, eBusiness Research Center, Smeal College of Business, Pennsylvania State University, University Park, PA, 1-32.

Porter, M.E. and Stern, S. (2001). Innovation: location matters. MIT Sloan Management Review, 42(4), 28-36.

Powell, T.C. (1995). Total quality management as competitive advantage: a review and empirical study. Strategic Management Journal. 16, 15-37.

Prajogo, D. I. and S. W. Hong (2008). The effect of TQM on performance in R\&D environments: A perspective from South Korean firms. Technovation, 28(12), 855-863.

Prajogo, D. I., \& Sohal, A. S. (2003). The relationship between TQM practices, quality performance, and innovation performance: An empirical examination. International journal of quality \& reliability management, 20(8), 901-918.

Prajogo, D. I., \& Sohal, A. S. (2003). The relationship between TQM practices, quality performance, and innovation performance: An empirical examination. International journal of quality \& reliability management, 20(8), 901-918. 
Prajogo, D. I., \& Sohal, A. S. (2004). The multidimensionality of TQM practices in determining quality and innovation performance - an empirical examination. Technovation, 24(6), 443-453.

Prajogo, D. I., \& Sohal, A. S. (2004). The multidimensionality of TQM practices in determining quality and innovation performance - an empirical examination. Technovation, 24(6), 443-453.

Prajogo, D. I., \& Sohal, A. S. (2006). The integration of TQM and technology/R\&D management in determining quality and innovation performance. Omega, 34(3), 296-312.

Prajogo, D. I., \& Sohal, A. S. (2006). The integration of TQM and technology/R\&D management in determining quality and innovation performance. Omega, 34(3), 296-312.

Qureshi, T. M., Dar, I., \& Khan, M. A. (2008). Innovation Management: Types, Management Practices and Innovation Performance In Services Industry of Developing Economies. Communications of the IBIMA (International Business Information Management Association), 1.

Rahman S. Bullock P., (2005). Soft TQM hard TQM and organizational performance relationships: an empirical investigation. Omega, 33, 73-83.

Rao, M.P. (2006). A performance measurement system using a profit-linked multi-factor measurement model. Industrial Management \& Data Systems. 106(3), 362-79.

Reed, R. Lemak, D.J. Montgomery, J.C. (1996). Beyond process: TQM content and firm performance. Academy of Management Review, 21 (1), 173-202.

Roberts, P.W. (1999). Product innovation, product-market competition and persistent profitability in the U.S. pharmaceutical industry. Strategic Management journal, 20(7), 655-670.

Roberts, P.W. (1999). Product innovation, product-market competition and persistent profitability in the U.S. pharmaceutical industry. Strategic Management journal, 20(7), 655-670.

Samat, N., Ramayah, T. and Saad, N.M. (2006). TQM practices, service quality, and market orientation: some empirical evidence from developing country. Management Research News, 29(11), 713-28.

Samson, D. and Terziovski, M. (1999). The relationship between total quality management practices and operational performance. Journal of Operations Management, 17,393-409.

Samson, D. and Terziovski, M. (1999).The relationship between total quality management practices and operational performance. Journal of Operations Management, 17,393-409.

Schulteß, P., Wegener, S., Neus, A., \& Satzger, G. (2010). Innovating for and with your service customers: An assessment of the current practice of collaborative service innovation in Germany. Procedia-Social and Behavioral Sciences, 2(4), 65036515.

Shams-ur Rahman, (2001). A comparative study of TQM practice and organizational performance of SMEs with and without ISO 9000 certification. International Journal of Quality \& Reliability Management, 18(1), 35 - 49.

Simon, A., \& Honore Petnji Yaya, L. (2012). Improving innovation and customer satisfaction through systems integration. Industrial Management \& Data Systems, 112(7), 1026-1043.

Simon, A., \& Honore Petnji Yaya, L. (2012). Improving innovation and customer satisfaction through systems integration. Industrial Management \& Data Systems, 112(7), 1026-1043.

Singh, P. J. \& Smith, A. (2004). Relationship between TQM and innovation: an empirical study. Journal of Manufacturing Technology Management, 15(5), 394-01.

Sit, W.Y., Ooi, K.B., Lin, B. and Chong, A.Y.L. (2009). TQM and customer satisfaction in Malaysia's service sector. Industrial Management \& Data Systems, 109(7), 957-75.

Soderquist, K. (1996). Managing innovation in SMES: a comparison of companies in the UK, France and Portugal. International Journal of Technology Management, 12(3), 291-305.

Stark, J. (2011). Product lifecycle management (pp. 1-16). Springer London.

Sureshchandar, G. S., Rajendran, C., \& Anantharaman, R. N. (2001). A holistic model for total quality service. International Journal of Service Industry Management, 12(4), 378-412.

Terzioski, M., Samson, D., 2000. The effect of company size on the relationship between TQM strategy and organizational performance. TQM Magazine, 12 (2), 144-148.

Thai Hoang, D., Igel, B., \& Laosirihongthong, T. (2006). The impact of total quality management on innovation: Findings from a developing country.International journal of quality \& reliability management, 23(9), 1092-1117.

Therrien, P., Doloreux, D. and Chamberlin, T., (2011). Innovation novelty and (commercial) performance in the service sector: A Canadian firmlevel analysis. Technovation, (31), 655-665.

Varis, M., \& Littunen, H. (2010). Types of innovation, sources of information and performance in entrepreneurial SMEs. European Journal of Innovation Management, 13(2), 128-154.

Varis, M., \& Littunen, H. (2010). Types of innovation, sources of information and performance in entrepreneurial SMEs. European Journal of Innovation Management, 13(2), 128-154.

Varis, M., \& Littunen, H. (2010). Types of innovation, sources of information and performance in entrepreneurial SMEs. European Journal of Innovation Management, 13(2), 128-154.

Waldman, D. A., \& Gopalakrishman, M. (1996). Operational, organizational, and human resource factors predictive of customer 
perceptions of service quality. Journal of Quality Management, 1(1), 91-107.

Waldman, D.A. (1994). The contributions of total quality management to a theory of work performance. Academy of Management Review, 19(3), 510-36.

Warihay, F.D. (1993). Total quality in service organizations. Journal for Quality and Participation, 16(3), 6-8.

Wolff, J.A. and Pett, T.L. (2006). Small-firm performance: modelling the role of product and process improvements. Journal of Small Business Management, 44(2), 268-84.

Yeh-Yun Lin, C., \& Yi-Ching Chen, M. (2007). Does innovation lead to performance? An empirical study of SMEs in Taiwan. Management Research News, 30(2), 115-132.

York, K. M., \& Miree, C. E. (2004). Causation or covariation: an empirical re-examination of the link between TQM and financial performance. Journal of Operations Management, 22(3), 291-311.

Zehir, C., Ertosun, Ö. G., Zehir, S., \& Müceldilli, B. (2012). Total Quality Management Practices' Effects on Quality Performance and Innovative Performance. Procedia-Social and Behavioral Sciences, 41, 273-280.

Zhang, Z., Waszink, A. and Wijngaard, J. (2000). An instrument for measuring TQM implementation for Chinese manufacturing companies. International Journal of Quality \& Reliability Management, 17(7), 730-55. 